\title{
Research on Occupational Burnout of Private University Teachers in Hainan
}

\author{
Lin Wang ${ }^{1, a}$ and Gaozhi Liu ${ }^{2, b}$ \\ ${ }^{1}$ School of Business Administration, Haikou College of Economics, Haikou 571127, China \\ ${ }^{2}$ School of Tourism and Civil Aviation Management, Haikou College of Economics, Haikou 571127, \\ China \\ awhu05@qq.com, b34320679@qq.com
}

Keywords: Job Burnout, Private Colleges, College Teachers.

\begin{abstract}
In recent years, private colleges and universities in Hainan Province developed rapidly, The working conditions of teachers in private colleges and universities have drawn more and more attention from all parties. Taking Hainan Province private university teachers as the research object, the paper selects the authoritative job satisfaction and burnout list by using questionnaire, interview and literature research, and analyzes the data with SPSS20.0 statistical software. Hainan Province found that private college teachers generally appeared mild occupation burnout, teaching teachers occupation burnout is more prominent in the 3-5 years. This paper from individuals, organizations and society three aspects of countermeasures to alleviate the private college teachers occupation burnout and improve job satisfaction.
\end{abstract}

\section{Introduction}

With the advent of knowledge economy era, "education" has become the focus of the world's attention, teachers' occupation burnout has attracted wide attention of scholars at home and abroad. Occupation burnout refers to modern people engaged in the same work for a long time, psychological conflict or start to work with emotions, is a kind of negative mentality of modern people.

In recent years, rapid development of China's higher education, and private colleges and universities is an important part of the development of higher education in China, according to the Ministry of education official data show that as of May 2016, China Normal 735 private colleges and universities, private colleges and universities accounted for the national total of Colleges and universities as our country higher education underdeveloped provinces in Hainan $25.53 \%$. Province, a total of 19 ordinary universities, including 8 private schools, accounting for $42.11 \%$. ranks first in the country. With the rapid development of private universities, as teachers occupation burnout subject of private universities has become increasingly prominent. The level of stability and the quality of teaching which seriously affect teachers. Therefore, this article through the form of questionnaire the private universities in Hainan province teachers conducted a sample survey, trying to find some rules and characteristics in the hope for the school to provide a theoretical reference to help alleviate the society, private colleges and Universities Teachers' Job Burnout.

\section{Hainan Private University Teachers Burnout Status Investigation}

\section{1 the Basic Situation of Teachers in Private Colleges in Hainan}

In this paper, stratified random sampling of 8 private colleges of Hainan Province, issued 200 questionnaires, 160 questionnaires were collected, eligible 20 questionnaires, 140 valid questionnaires were obtained, the basic characteristics of effective questionnaire recovery rate reached $70 \%$. by the obtained effective subjects: age of teachers in private colleges overall relatively young among them, 29 to 39 years old teachers accounted for $60.7 \%$, under 26 years of age and seniority of teachers accounted for $10.7 \%$, between $3-5$ years in the majority; the proportion 
of women in the majority; and the number of lecturers teachers in private colleges in the highest proportion, postgraduate education teachers accounted for $62.1 \%$ of the total number, the highest proportion.

Compared to the teachers and public colleges and universities, the basic situation of private college teachers in Hainan province is more obvious, as shown in Table 1.

Table.1. The basic situation of teachers in public universities and teachers in private colleges in

Hainan

\begin{tabular}{|c|c|c|}
\hline & Public institutions & Private institutions \\
\hline gender & $\begin{array}{l}\text { The balance between men and } \\
\text { women in Liberal Arts Colleges } \\
\text { Engineering colleges, more men } \\
\text { and women less }\end{array}$ & $\begin{array}{l}\text { The proportion of women is } \\
\text { larger than that of men }\end{array}$ \\
\hline Number of teachers & About 700-1500 people & About 500-600 people \\
\hline marital status & Married majority & Unmarried majority \\
\hline salary & $\begin{array}{l}\text { Lecturer:40000-90000/ years } \\
\text { Associate } \quad \text { Professor: } \\
\text { 70000-150000/years } \\
\text { Professor: 80000-200000 / year }\end{array}$ & $\begin{array}{l}\text { Lecturer:36000-60000/ years } \\
\text { Associate } \quad \text { Professor: } \\
\text { 70000-120000/years } \\
\text { Professor:100000-150000/ year }\end{array}$ \\
\hline Welfare & $\begin{array}{l}\text { Holiday allowance } \\
\text { Insurance and Housing Fund } \\
\text { Organizing1-2 domestic tours per } \\
\text { year } \\
\text { Sufficient funds for scientific } \\
\text { research }\end{array}$ & $\begin{array}{l}\text { Holiday allowance } \\
\text { Insurance and Housing Fund } \\
\text { 1-2 times the island's Tourism } \\
\text { Organization per year } \\
\text { Relatively few scientific } \\
\text { research funds }\end{array}$ \\
\hline class hour & 10-18 knots / week & 12-26 knots / week \\
\hline main funds & National financial allocations & enterprise \\
\hline
\end{tabular}

The table 1 shows that the main source of funding of private colleges in Hainan province is the enterprise, the number of teachers and public institutions is relatively less, the amount of hours per week of teachers is relatively large, and the overall salary level is lower than that of the public institutions, scientific research funds are relatively small.

\subsection{Hainan Province, Private University Teachers Burnout Survey}

This questionnaire mainly divides the teachers according to "teaching age", and makes the preparation around the three aspects of job burnout dehumanization, low sense of accomplishment and emotional exhaustion, mainly from the aspects of student's problems, workload, management environment, work pressure, interpersonal relationship, Role conflict 6 dimensions to measure. The questionnaire adopts 5 points scoring method, the higher the score burnout feeling stronger. Median value of 3 points, less than 3 points that there is no burnout phenomenon, higher than 3 points indicates that burnout has occurred. The questionnaire is divided into three parts: basic information, occupational burnout scale and open question. Table 2 shows the basic status of each dimension.

Table.2. Different Teaching Ages Hainan Province, private university teachers burnout statistics

\begin{tabular}{|c|c|c|c|c|c|c|c|}
\hline \multicolumn{8}{|c|}{ Mean value } \\
\hline \multicolumn{3}{|c|}{ Low sense of accomplishment } & \multicolumn{2}{|c|}{ Deindividuation } & \multicolumn{2}{|c|}{$\begin{array}{l}\text { Emotional } \\
\text { exhaustion }\end{array}$} & \multirow[b]{2}{*}{ overall } \\
\hline $\begin{array}{c}\text { Teaching } \\
\text { age }\end{array}$ & $\begin{array}{c}\text { Student } \\
\text { problem }\end{array}$ & Workload & $\begin{array}{c}\text { Relation } \\
\text { ship }\end{array}$ & $\begin{array}{l}\text { Manage the } \\
\text { environment }\end{array}$ & $\begin{array}{c}\text { Work } \\
\text { pressure }\end{array}$ & $\begin{array}{c}\text { Role } \\
\text { conflict }\end{array}$ & \\
\hline 0 -2years & 1.73 & 3.3 & 2.3 & 2.78 & 3.01 & 2.86 & 2.66 \\
\hline 3-5years & 3.03 & 3.78 & 3.37 & 3.41 & 3.65 & 3.12 & 3.45 \\
\hline $6-10$ years & 2.56 & 3.44 & 3.21 & 3.20 & 3.38 & 3.05 & 3.12 \\
\hline $\begin{array}{c}\text { Over } 10 \\
\text { years }\end{array}$ & 2.78 & 3.31 & 2.93 & 3.05 & 3.17 & 2.64 & .98 \\
\hline
\end{tabular}

Table 2 shows the different teaching experience of teachers in private colleges in Hainan Province, the average score of each dimension and the total mean, see from the table: teacher 
seniority in the overall mean 0-2 years below the median 3, that does not appear in this stage also occupation burnout of teachers; the highest seniority of the teachers in the 3-5 years the overall average score 3.45 higher than the median 3 , indicating teachers occupation burnout phenomenon in this period is more prominent, teacher seniority in the overall mean 6-10 was 3.12 higher than the median 3, indicating the peak of this phase of the teacher occupation burnout continues, but eased; taught more than 10 years of age in the teachers' overall average is 2.98 below the median of 3 , at this stage the teacher occupation burnout significantly reduced. The table can also be found that teachers are the highest in the "work load" and "working pressure" of this dimension scores, that teachers burnout in two dimensions The strongest

The image expression of job burnout level of teachers in private colleges and universities in Hainan province

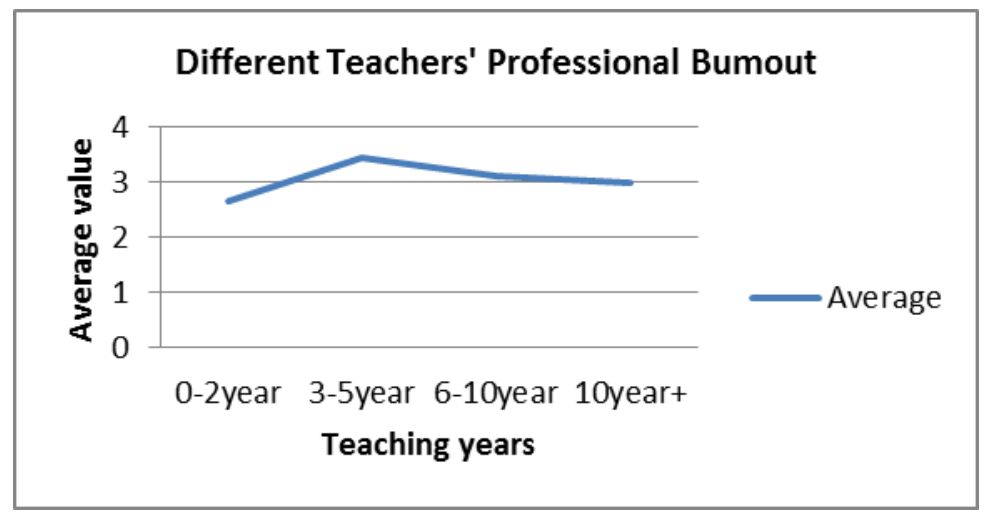

Figure.1. Hainan Province, private colleges and universities teachers of different teaching age teacher burnout line chart

From figure 1, it is not difficult to find that Hainan province by the local college teachers' job burnout affected by teaching years, 3 to 5 years' experience is Hainan province by the local college teachers' job burnout of peak, gradually increased along with the teaching experience of teachers' job burnout is gradually reduced.

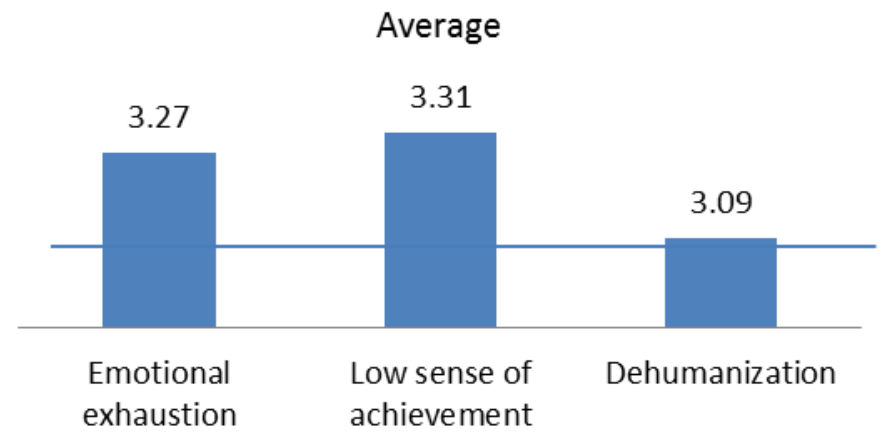

Figure.2. Overall scores of occupational burnout among private university teachers in Hainan Province

We can see from Figure 2, Hainan Province, private university teachers in emotional exhaustion, low sense of accomplishment, to the level of humanity in the three levels are higher than the mean value of 3, indicating that Hainan Province, private colleges and universities teachers as a whole have appeared in job burnout; of which " Low sense of accomplishment, "the highest score at this level, indicating that Hainan Province, private colleges and universities teachers in the" low sense of accomplishment, "the level of occupational burnout most serious.

\subsection{Factors and Existing Problems of Job Burnout of Private University Teachers in Hainan Province}

The influence factors of private colleges in Hainan province teachers occupation burnout is mainly divided into demographic variables, depersonalization, emotional exhaustion and achievement of four aspects, including the demographic variables mainly related to age, gender, 
marital status, education level, age and so on.

The main problems in the occupation burnout in private universities in Hainan province the current teachers for teachers often feel a heavy burden of work pressure, in the work often feel tired; often lose patience in the work of life; indifference, pessimism; job satisfaction is low.

\section{Hainan Province, Private Colleges and Universities Teachers Cause Job Burnout Reasons}

\subsection{Personal Level}

Compared with the public university teachers, teachers in private colleges enthusiasm is low, low job satisfaction, which leads to low sense of achievement; private college teachers' daily workload, the amount of hours, it requires teachers to have good psychological quality, excessive external pressure will induce occupation burnout.

\subsection{Level of Organization}

The construction of organizational culture vacancy, the working environment is not ideal; the management system is not perfect, efficiency is not high, teachers' interpersonal relationship; the quality of students in private schools than public schools, teachers often produce fatigue, these factors will induce teachers' occupation burnout.

\subsection{Level of Society}

Social concern for the private college teachers is low, the government policy support of public colleges; teachers' welfare gap between public colleges and private colleges teachers; private college teachers' social recognition is less than public school teachers; all these factors lead to private college teachers' work enthusiasm is hit, resulting in occupation burnout.

\section{Countermeasures for Overcoming Job Burnout of Private University Teachers in Hainan Province}

\subsection{Personal Level}

4.1.1 Teachers should set up a positive and optimistic attitude towards life, and pay attention to their mental health in real time. They can understand themselves through psychological interviews, and adjust them accordingly.

4.1.2 Teachers Set up Short-term Goals and Long-term Goals. In order to overcome burnout, teachers should set up short-term goals and long-term goals for themselves, constantly improve and innovate teaching methods, and find pleasure in Teaching.

4.1.3 Teachers Can Alleviate Their Psychological Pressure Through Exercise and Diet. Teachers should learn with reasonable distribution of their time, know how to relax and take part in some outdoor activities, to strengthen international exchanges.

\subsection{Organizational Level}

4.2.1 To Improve the Students' Quality and Teachers' Welfare. School should improve the quality and level of students, to strengthen the quality education construction of students, reduce the teacher burnout and psychological pressure; organization of campus cultural activities and other ways to improve the staff's work enthusiasm, reduce the occupation burnout.

4.2.2 Reduces the Psychological Pressure of Teachers. Through the establishment of mental health room for teachers and staff, the mood catharsis room provides a room for releasing the pressure for the staff and workers, and avoids the phenomenon of emotional exhaustion.

4.2.3 Reduce the Teachers Strength, Give Teachers Fully Research Time and Conditions. According to the teacher's ability to allocate some challenging work, can improve the teachers' sense of achievement, let teachers feel wanted and accepted, and can keep the teacher work fresh, to effectively relieve job burnout effect. 


\subsection{Social Level}

4.3.1 Provide policy support and funding to support the government. The government should strengthen the private college teachers' welfare, increase the degree of attention, and reduce the gap. Many teachers of public universities issued "protection policy for private universities such as files, to increase private university policy support and financial support.

4.3.2 Seeking Social Support. To establish extensive social support network, provide a good social environment for teachers. Guide by means of national policy and public opinion, promote the formation of the whole society to respect teachers' consciousness tendency and psychological atmosphere.

\section{Conclusion}

The phenomenon of private colleges in Hainan province teachers occupation burnout significantly, the emergence of this situation is caused by a variety of factors, such as the private college teachers' sense of achievement is not high, heavy workload, less time for research, teachers' salary is low, work pressure and so on. To solve these problems, we should from individuals, organizations, three levels of society to alleviate or prevent the private colleges in Hainan province teachers occupation burnout, improve teachers' job satisfaction.

This paper draws a conclusion through questionnaires and interviews, but there are still many shortcomings. Such as the sample size range is narrow, just select the "teaching" of the independent variables are divided on Teachers' conclusion single, lack of in-depth analysis, the representative is not strong enough, can only represent large private teachers in a small part of the teacher's point of view, these will be the focus of future studies.

\section{References}

[1] Zhao Kun. Study on Job Burnout of non teaching staff in private universities [D]. Guangxi Normal University, 2014.

[2] Liu Junying. Professional identity, job burnout and work shaping of college teachers [D]. Inner Mongolia Normal University,2014.

[3] Cheng Guilin. Private college teachers' satisfaction and the relationship between occupation burnout [J]. China adult education, 2012,06:115-116.

[4] Ming akigumo. Influence of Shanghai private college sports teachers occupation burnout factors and Countermeasures of contemporary [J]. sports science and technology, 2012,18:1-2.

[5] Lei Jing. Investigation on Job Burnout of teachers in Yucai College of Southwestern University [D]. Southwestern University, 2013.

[6] Wu Xian. Research on the relationship between job satisfaction and job burnout of research university teachers [D]. Dalian University of Technology, 2009.

[7] Lu Li. Relationship between job burnout and job satisfaction and social support of university teachers [D]. Huazhong University of Science and Technology, 2010.

[8] Zhang Nannan, Zhou Yuankuan. Study on job burnout and locus of control of private college teachers in Shanghai [J]. education and Vocational Education Industry, 2011,24:72-74. 